\title{
THE EFFECT OF NEW IDENTITY, NEW IMAGE, AND REPOSITIONING AS A PROCESS OF REBRANDING TOWARD BRAND LOYALTY, BRAND ASSOCIATIONS, PERCEIVED QUALITY AS PART OF BRAND EQUITY
}

\author{
Setiani Titi* \\ Master's Program in Communication, Faculty of Social and Political Sciences, \\ University of Brawijaya, Indonesia \\ Antoni, Sujoko Anang \\ Faculty of Social and Political Sciences, University of Brawijaya, Indonesia \\ *E-mail: setianititi@yahoo.com
}

\begin{abstract}
Media companies are growing rapidly, along with technological advances, where the success of a media must be supported by brand management. This study examines corporate rebranding by changing name, logo and slogan in influencing brand equity in media companies. Not only to measure the concepts of corporate rebranding and brand equity, the study also examines the relationships between indicators that are used as variables, namely new identity with brand association, new image with brand association, new image with perceived quality, new image with brand loyalty, repositioning with brand association, repositioning with perceived quality and repositioning with brand loyalty. The method of analysis in this study using multiple linear with SPSS analysis. 110 respondents who are advertiser of Radio Kencana Malang in 2017. This study shows a significant effect between corporate rebranding to brand equity simultaneously, new identity with brand association, new image with brand association, repositioning with brand association, new identity with perceived quality, new image with perceived quality, repositioning with brand loyalty, and new identity with brand loyalty. However, there is no significant effect between repositioning with perceived quality and new image with brand loyalty on Radio Kencana Malang.
\end{abstract}

\section{KEY WORDS}

Corporate rebranding, brand equity, media firm, indicators, loyalty.

Radio as a form of conventional mass media experienced strong competition. This can be seen from the number of radio in Indonesia. Like data sourced from Kominfo in 2016, almost ten years since the birth of Law No. 32 about Broadcasting, quantitatively the number of radio broadcasts in Indonesia has increased. If in 1998 the number of radio stations less than 1000 currently there are approximately 2,845 radio broadcasters. Furthermore, it is mentioned that the number will increase again with the addition of FM channel from 3.29 to 8.210 based on Regulation for Minister of Communication and Information Technology No. 13 year 2010 regarding the second amendment of Minister of Transportation No. 15 year 2003 (Kominfo, 2016).

However, the growth in radio numbers previously described is not accompanied by an increase in the number of listeners. It can be seen from Nielsen Radio Audience Measurement survey that the percentage of listeners who listen to radio is still small compared to other mass media, such as television media (96\%), outdoor media $(52 \%)$, internet $(40 \%)$ and radio at $38 \%$ in the third quarter of 2016 . For Malang city itself, according to data from the Office of Communications and Information of Malang City Government in 2012, there are 12 private radio and 7 community radio (Diskominfo, 2012). Radio competition in Malang city is also felt tight with the existence of several segmentation of the same private radio. Competition makes some radio do a major reshuffle in order to reach the target market that allows make the radio more desirable. 
In Malang city, Radio Kencana has started in the frequency of 98.6 FM since 2007. Until then, in 2015, made some changes in the slogan that turned into "Radio Kencana selected music radio, Malang city listen to Radio Kencana". In fact, some programs have changed with the emergence of new programs. The change also replaced the marketing strategy that initially focused on the marketing of on-air programs, then added with off-air marketing and online. In 2015 also, there is a change of regulation from Kominfo, which is intended for some radio in Malang city which permission has not been officially out, to immediately move its frequency to the frequency set by Kominfo. The initial frequency of Radio Kencana is 98.6 FM. Then, Radio Kencana is required to move to frequency $91.9 \mathrm{FM}$ because the previous frequency will be emptied. However, it turns out the frequency of 98.6 is used by radio competitors in the city of Malang. That is also what makes the management feel must try harder to inform about the new frequency transfer because there is a fierce competition with the radio competitors who use the old frequency of Radio Kencana. At this moment, Radio Kencana as well as taking the decision to change the logo that is considered to better represent the vision and mission of the company as a radio of young people and young workers in order to increase the profit of Radio Kencana and increase the number of advertisers.

With these changes, it affects the company's finances. This happens because there is a change in the number of clients who advertise on Radio Kencana. By year, the number of advertisers in 2014 (115 clients) increased by 2015 (119 clients). However, the number of advertisers is stagnant by 2016 (119 clients). The stagnant amount raises its own question about the cause of stagnation. By 2015 , when a rebranding is done, a decrease in advertiser numbers occurs in May ( 25 clients), June (17 clients), and July (9 clients). In addition, why the frequency shift is of concern to the author, because for the radio station, changing the frequency is the same as changing the name. Because the frequency is usually always mentioned along with the name. So, the frequency is also part of the identity of a radio. Moreover, the old frequency is used by competitor radio. From the above exposure, it can be concluded that, at the time of frequency shift, Radio Kencana changed name, logo change and slogan change in 2015.

The reshuffle is done with a change of marketing strategy related to the brand. One of branding strategy is also known as rebranding. Rebranding occurs when a company renews, renames or change positioning. Gaurav (2008) states that corporate rebranding is a powerful and trusted tool for changing corporate identity, logos and slogans to show a new image. Furthermore Gaurav (2008) states that, basically corporate rebranding is a strategy in getting new identity and brand new image. Corporate rebranding is very important to clarify and strengthen positioning. Einwiller \& Will (2002) explain that corporate rebranding as a planned and systematically planned change strategy to maintain a good brand image and create a new brand image better. Rebranding and image are closely related, in accordance with the results of the research of Lee et al., (2011) which states that, brand image improvement affects brand equity (perceived quality, brand association and brand loyalty).

After the company has conducted a rebranding activity, the company must also know how the public response and how strong the company brand in the community. Steps taken to determine brand strength is to measure brand equity. Brand equity is very important because it can help the company in showing the uniqueness that is different from other companies and also very profitable in a very competitive market circumstances (Kim et al, 2011). Many companies are doing rebranding to increase their brand equity (Kapferer in May Tea, 2009). Maintaining brand equity is a challenge for the company. The linkage between corporate rebranding and brand equity is also explained by Muzellec and Lambkin (2006) that, rebranding helps create a better brand equity. Agreeing with the research, May Tea (2009) found that rebranding affects brand equity. However, there are other studies that apply brand equity in mass media conducted by Oyedeji (2007). His research explains the impact of audiences' ideology associated with media channels and brand equity, found that not all items of brand equity have a significant effect. The results show that brand awareness has no significant effect, while brand association, perceived quality and brand loyalty show significant relationship to media channel. Then, in research by Porral (2014) which also 
applies the measurement of brand equity in media companies. The results show a positive relationship between brand equity media and media credibility. The two most significant items of brand equity, brand association and brand loyalty have a significant influence on the credibility of media channels.

From the explanation above, there is a gap which is not all items in the brand equity has a significant effect when applied in a media company that sees the brand equity of the audience. The most influential brand equity items are brand association, perceived quality and brand loyalty. Then, because this study is also related to the media economy in terms of management strategy, then this research will try to see from the side advertiser as stakeholders that influence the media company financially. In previous research, all done on conventional media, in the form of TV and newspaper, hence this research will try to do research on different conventional media, that is radio. Therefore, this study focuses on measuring brand association, perceived quality and brand loyalty after the corporate rebranding by Radio Kencana Kota Malang on consumer (advertiser). The focus for corporate rebranding activities on Radio Kencana in this research is on the change of name, logo and slogan.

\section{LITERATUR REVIEW}

Muzellec et al. (2003) defines corporate rebranding as the practice of building a new name that represents a different position in the stakeholder's mindset and an identity different from that of competitors. Muzellec and Lambkin (2006) further clarify the definition of corporate rebranding as the creation of a new name, term, symbol, design, or combination of novelty for an established brand with the intention of developing a new and different position in the minds of the stakeholders and competitors. Gaurav (2008) states that corporate rebranding is a powerful and trusted tool for changing corporate identity, logos and slogans to show a new image. Furthermore Gaurav (2008) states that, basically corporate rebranding is a strategy in getting new identity and brand new image. Corporate rebranding is very important to clarify and strengthen positioning.

Muzellec \& Lambkin (2006) discloses a corporate rebranding model that combines the causes or supporting factors (ownership structure, corporate strategy, competition and external environment) that leads to corporate rebranding decisions, identifies key objectives (corporate identity and image) of corporate rebranding and highlight the importance of engaging both internal and external stakeholders in the rebranding process. In this model, rebranding is conceptualized as a change in the personal identity of a company and / or an attempt to alter perceptions of the image between external stakeholders. Basically, rebranding is a strategy to get new identity and brand image by changing the name, logo and slogan. Successful rebranding is what transforms a brand into offering new identities and images, and helps companies change positions in an effort to retain existing customers and attract new customers. Rebranding is very important to clarify and strengthen positioning. Thus, the variables in this study that are corporate rebranding are measured by adopting the indicators: New identity, New image, and Repositioning (Caniago, 2014; Collange, 2008; Simonim \& Ruth, 1998).

According to Abrams \& LaPlante (2008), identity is a set of characteristics that allow consumers to recognize the company as a separate and unique entity. The identity also will make the company has a character that determines the similarities and differences with others. Furthermore also mentioned that there are main elements of identity, namely name, logo, slogan and image. Image has a relationship with the identity of the company, because the formation of the image comes from the identity formed by a company. Further mentioned that, knowledge of a person, experience, behavior and emotions will impact on the image formed in the mind of someone about an object, will form the image of the company.

One of the rebranding activities is repositioning (Muzellec \& Lambkin, 2006) where the brand's marketing position is changed (Merrilees \& Miller, 2008), and new positions must be developed and delivered to the public (Muzellec \& Lambkin, 2006). A revitalization of a brand position is what keeps a brand fresh and in line with current market conditions in order to 
adapt and anticipate customer needs (Merrilees \& Miller, 2008). Finally, the right repositioning of the market can result in a better brand association on the market and as consumers wish (Muzellec \& Lambkin, 2006).

Aaker (1991) defines brand equity as a set of assets and liabilities related to a brand, name and symbol, which may increase or decrease the value provided by the product or service to the company and / or its consumer. There are two general motivations in studying brand equity as described by Keller (1993). First, the financial-based motivation to accurately estimate the value of a brand related to accounting activities (valuation of corporate assets). Second, brand equity arises from a strategy-based motivation to improve marketing productivity. Given the higher costs and tighter competition, so companies are trying to improve their marketing cost efficiency. As a result, marketers need a deeper understanding of consumer behavior as a basis for making better strategic decisions about the definition of target market and product positioning, as well as better tactical decisions about a particular marketing mix.

Brand equity is not only used in products only, but also applies to services, one of them media. As described by Oyedeji (2007) that researchers have used the theory of brand equity as the theoretical basis for studying various aspects of media management. ChanOlmsted \& Kim (2001) made a survey on the leadership of a private TV station. Leaders agree that branding is important, but should be linked to other tactical strategies such as the credibility of local news, network affiliation image, media promotion strategies and logo design. In addition, McDowell \& Sutherland (2000) use brand equity to analyze the brand equity of a TV program. Then the study found that the higher the CBBE of a program, it will help generate more audience. Further, the study concludes that program equity increases the number of audiences changing channels and strengthening consumer loyalty. To measure brand equity in this study, researchers used a model according to Aaker (1991) which has been widely used and empirically tested. However, only 3 dimensions are consistent with the research gap, namely Brand Association, Perceived Quality and Brand Loyalty. This study also replicates the question from Tong \& Hawley (2009).

Aaker (1991) states that brand association is anything related to the memory of a brand. Associations to a brand are numerous, but not all of them have meaning. A collection of associations that have meaning will give rise to a series called brand image. It further argues that brand association reflects the imaging of a brand to a particular impression in relation to customs, lifestyles, benefits, product attributes, geographic, price, competitors, celebrities and others (Aaker in Durianto et al., 2004). Brand association deals with brand image formation of products, many types of associations related to performance and brand image, however, the brand association that makes up the brand image can be grouped based on three important dimensions (Keller, 2003), strength, favorability, uniques. Brand equity manifests when consumers have a high level of awareness and power, gain fun and uniqueness incorporated in consumer memory (Tong \& Hawley, 2009).

Perceived quality reflects the customer's perception of the overall quality / superiority of a product or service in respect of the intended purpose (Aaker in Durianto et al., 2004). Perceived quality is a key aspect in customer based brand equity (Aaker, 1996). This is not the real quality of a product, but the consumer's perception of the overall quality or superiority of the product (or service) relates to a predetermined, relative or alternative purpose (Zeithmal, 1988). Aaker (1991) mentions that perceived quality provides brand value in several ways, namely: 1) high quality gives consumers a good reason to buy brands and allows brands to differentiate a brand from their competitors 2) to set a premium price 3 ) has a strong foundation for brand extension (Aaker, 1996).

Brand loyalty reflects the level of consumer engagement with a product brand (Aaker in Durianto et al., 2004). Brand loyalty is the "heart" of brand equity. This is one of the main components (Aaker, 1991). Tong \& Hawley (2009) states that brand loyalty can be seen from the perspective of consumer behavior and buying behavior. According to Aaker (1991) brand loyalty adds considerable value to a brand and / or company, as it provides a series of consumer buying habits over a long period of time. Loyal customers, have a small possibility to switch to brand competitors due to price. In addition, loyal consumers also make 
purchases more often than unfaithful customers (Bowen and Shoemaker in Tong \& Hawley, 2009).

\section{METHODS OF RESEARCH}

This study uses a quantitative approach. Based on the hypothesis formulated, this research includes correlational research (Neuman, 2000) and regression with data collection methods, distributing questionnaires conducted online to advertisers Radio Kencana. The questionnaire was distributed to 125 advertisers of Radio Kencana, but only 110 questionnaires were returned. While data analysis, using multiple linear analysis method with SPSS.

The concepts and variables in this research is Corporate Rebranding which adopted from Caniago (2014) which consists of new identity, new image and repositioning. Then the variables of the concept were developed by measuring the new identity by Muzellec \& Lambkin (2006) and Gaurav (2008), new image by Collange (2008) in Delassus \& Decotes (2012) and measuring the repositioning suitability by Simonim \& Ruth (1998) cited from Nath Hanh Le et al., (2014). For Brand Equity concept consisting of brand association, perceived quality and brand loyalty, measured by adopting from Tong \& Hawley (2009). Here is a hypothetical model of research:

$\mathrm{H} 1$ : Corporate Rebranding $(\mathrm{X})$ effect on Brand Equity $(\mathrm{Y})$ simultaneously;

$H 2$ : New identity $\left(X_{1}\right)$ effect on brand association $\left(Y_{1}\right)$;

H3: New identity $\left(X_{1}\right)$ effect on perceived quality $\left(Y_{2}\right)$;

$\mathrm{H}$ 4: New identity $\left(\mathrm{X}_{1}\right)$ effect on brand loyalty $\left(\mathrm{Y}_{3}\right)$;

$\mathrm{H}$ : New image $\left(\mathrm{X}_{2}\right)$ effect on brand association $\left(\mathrm{Y}_{1}\right)$;

H6: New image $\left(X_{2}\right)$ effect on perceived quality $\left(Y_{2}\right)$;

$\mathrm{H} 7$ : New image $\left(\mathrm{X}_{2}\right)$ effect on brand loyalty $\left(\mathrm{Y}_{3}\right)$;

H8: Repositioning $\left(X_{3}\right)$ effect on brand association $\left(Y_{1}\right)$;

H9: Repositioning $\left(X_{3}\right)$ effect on perceived quality $\left(Y_{2}\right)$;

$\mathrm{H} 10$ : Repositioning $\left(\mathrm{X}_{3}\right)$ effect on brand loyalty $\left(\mathrm{Y}_{3}\right)$.

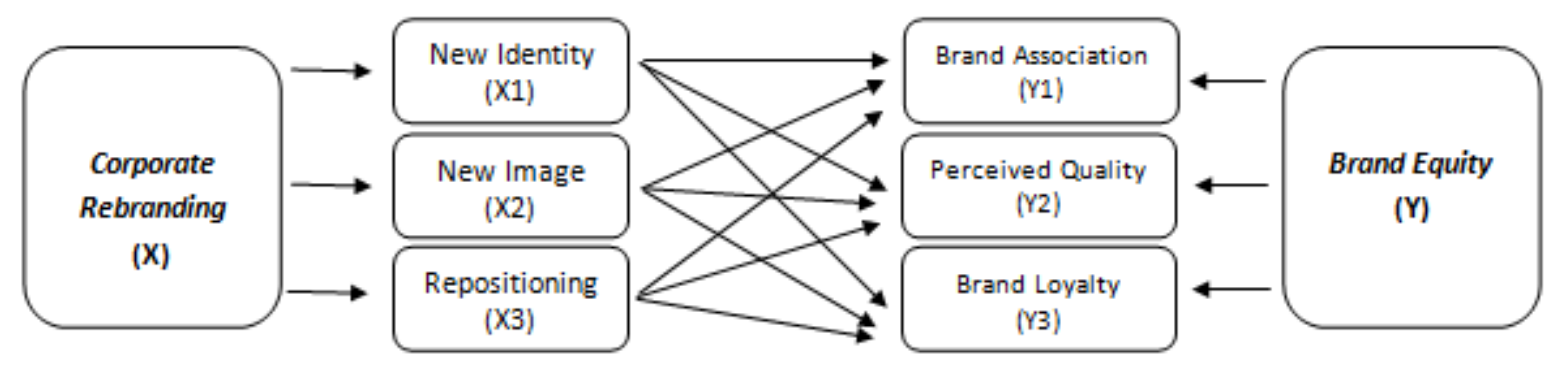

Figure 1 - Model of Research Hypothesis

\section{RESULTS AND DISCUSSION}

Criteria of respondents in this study were men and women who are advertisers (advertisers) in Radio Kencana during 2017. The retrieval of respondents in this study was taken by using the total sampling method. Respondents collected in this study were 110 clients from various companies and organizations that advertise on Radio Kencana. Advertisers who advertise on Radio Kencana on this research are advertisers who advertise for the year 2017, be it advertisers who advertise on air, off water and also online. In detail, the characteristics of respondents can be seen in table 1.

From 110 respondents in this study, female respondents are more dominant than male respondents, as evident as $58.2 \%$ of respondents are women. Based on age classification of respondents ranged between the age of 15 years to 52 years. When viewed from the classification of respondents age, the clients of Radio Kencana who mostly are marketers, are respondents at the age of 26-30 years. 
Table 1 - Characteristics of respondents

\begin{tabular}{lccc}
\hline & Respondent characteristics & $\begin{array}{c}\text { amount } \\
(\text { person })\end{array}$ & $\begin{array}{c}\text { persentage } \\
(\%)\end{array}$ \\
\hline Gender & Male & 46 & 41.8 \\
& Female & 64 & 58.2 \\
Age (years) & Total & 110 & 100 \\
& $15-20$ years & 22 & 20 \\
& $21-25$ years & 24 & 21.8 \\
& $26-30$ years & 28 & 25.5 \\
& $31-35$ years & 22 & 20 \\
& $36-40$ years & 11 & 10 \\
& $>41$ years & 3 & 2.7 \\
\hline
\end{tabular}

Source: Authors own research results, 2018.

Corporate rebranding $(X)$ concept consisting of 3 variables: new identity, new image and repositioning. Each question on indicator obtained of Pearson correlation value ( $r$-value) for all over r-table $=0,361$ and also value significance $\leq 0,05$. Therefore, all questions are valid. While on Brand Equity $(\mathrm{Y})$ variable consisting of 3 indicator (brand association, perceived quality and brand loyalty) all questions also have value of Pearson correlation ( $r-$ value) more than $r$-table $=0,361$ with significance value $\leq 0,05$. This indicates that all of these questions are valid. Further reliability testing is performed only on valid items. In the concept of Rebranding $(X)$ and brand equity $(Y)$, the value of Alpha Cronbach coefficient is $\geq 0.6$ in each indicator so it is concluded that the question instrument used is reliable.

Table 2 - Anova $(\mathrm{X})$ to $(\mathrm{Y})$

\begin{tabular}{|c|c|c|c|c|c|c|}
\hline \multicolumn{2}{|c|}{ Model } & Sum of Squares & df & Mean Square & F & Sig. \\
\hline \multirow{3}{*}{1} & Regression & 1921.327 & 1 & 1921.327 & 155.848 & $.000^{\mathrm{D}}$ \\
\cline { 2 - 7 } & Residual & 1331.446 & 108 & 12.328 & & \\
\cline { 2 - 8 } & Total & 3252.773 & 109 & & & \\
\hline
\end{tabular}

Source: SPSS analysis.

Notes: a. Dependent Variabel: Y (Brand equity); b. Predictors: (Constant), $X$.

With a significance level of $0.000<0.05$, the regression model can be used to predict brand equity and it can be stated that there is a relationship between corporate corporate rebranding and brand equity. This is also reinforced by the number of significance in the table below which shows the significance of $<0.05$.

Table 3 - Coefficients table $X$ to $Y$

\begin{tabular}{|c|c|c|c|c|c|c|}
\hline \multirow{2}{*}{\multicolumn{2}{|c|}{ Model }} & \multicolumn{2}{|c|}{ Unstandardized Coefficients } & \multirow{2}{*}{$\begin{array}{c}\text { Standardized Coefficients } \\
\text { Beta } \\
\end{array}$} & \multirow{2}{*}{$t$} & \multirow{2}{*}{ Sig. } \\
\hline & & $\beta$ & Std. Error & & & \\
\hline \multirow{2}{*}{1} & (Constant) & 12.432 & 2.388 & & 5.205 & .000 \\
\hline & $\mathrm{X}$ & .458 & .037 & .769 & 12.484 & .000 \\
\hline
\end{tabular}

Source: SPSS analysis

Notes: a. Dependent Variabel: Y (Brand equity).

In the table above can be seen column beta $(\beta)$ on constant is 12,432 . The value of independent variable 0.458 , so the regression equation is $Y=a+b 1 X 1$ i.e $Y=12.432+$ $0.458 \times 1$. In $\mathrm{b}$ is positive signified it is an addition that states the change of average variable $Y$ for each change of variable $X$ for one unit. In testing the hypothesis obtained:

$$
\text { Brand equity }=12,432+(0,458) \text { Corporate rebranding }
$$
follows:

The following table of results research hypothesis testing using SPSS analysis is as 
Table 4 - Hypothesis Result

\begin{tabular}{|l|c|c|c|c|}
\hline \multicolumn{1}{|c|}{ Hypothesis } & $\begin{array}{c}\text { Standardized } \\
\text { Coefficients }(\beta)\end{array}$ & t- value & Sig. & Results \\
\hline Corporate Rebranding $(\mathrm{X}) \rightarrow$ Brand Equity $(\mathrm{Y})$ & 0.769 & 12.484 & 0.000 & Significant \\
\hline New Identity $\left(\mathrm{X}_{1}\right) \rightarrow$ Brand Association $\left(\mathrm{Y}_{1}\right)$ & 0.360 & 4.229 & 0.000 & Significant \\
\hline New Identity $\left(\mathrm{X}_{1}\right) \rightarrow$ Perceived Quality $\left(\mathrm{Y}_{2}\right)$ & 0.234 & 2.917 & 0.004 & Significant \\
\hline New Identity $\left(\mathrm{X}_{1}\right) \rightarrow$ Brand Loyalty $\left(\mathrm{Y}_{3}\right)$ & 0.649 & 9.135 & 0.000 & Significant \\
\hline New Image $\left(\mathrm{X}_{2}\right) \rightarrow$ Brand Association $\left(\mathrm{Y}_{1}\right)$ & 0.286 & 3.112 & 0.002 & Significant \\
\hline New Image $\left(\mathrm{X}_{2}\right) \rightarrow$ Perceived Quality $\left(\mathrm{Y}_{2}\right)$ & 0.549 & 6.356 & 0.000 & Significant \\
\hline New Image $\left(\mathrm{X}_{2}\right) \rightarrow$ Brand Loyalty $\left(\mathrm{Y}_{3}\right)$ & 0.125 & 1.638 & 0.104 & Not Significant \\
\hline Repositioning $\left(\mathrm{X}_{3}\right) \rightarrow$ Brand Association $\left(\mathrm{Y}_{1}\right)$ & 0.254 & 3.333 & 0.001 & Significant \\
\hline Repositioning $\left(\mathrm{X}_{3}\right) \rightarrow$ Perceived Quality $\left(\mathrm{Y}_{2}\right)$ & 0.072 & 1.006 & 0.317 & Not Significant \\
\hline Repositioning $\left(\mathrm{X}_{3}\right) \rightarrow$ Brand Loyalty $\left(\mathrm{Y}_{3}\right)$ & 0.201 & 3.166 & 0.002 & Significant \\
\hline
\end{tabular}

Source: SPSS analysis.

Based on the results of correlation and regression analysis in table 4, then obtained the following research results:

Statistically, it was found that a significant correlation between corporate rebranding and brand equity simultaneously. It can be seen from the anova table and the coefficient table showing the significance value $<0,05$, thus hypothesis 1 is accepted. It can be interpreted that advertiser perception to corporate rebranding consisting of identity, image and repositioning of Radio Kencana Malang increase, it will also increase brand equity from Radio Kencana. Conversely, if the advertisers perception decrease toward corporate rebranding efforts on Radio Kencana, it will decrease brand equity on Radio Kencana. The results of this study support previous study by Muzellece and Lambkin (2006) that corporate rebranding helps to create better brand equity. In line with the results of the study, Petburikal (2009) states that testing the relationship between corporate rebranding and brand equity shows significant results. He explained that corporate rebranding and demography can affect the company's brand equity and company performance (sales volume). This is reinforced by the results research conducted by May Tea (2009) who found that corporate rebranding has a significant correlation to brand equity. However, the difference in the May Tea study (2009) shows that corporate rebranding indicators most influence repositioning, whereas in this study, the most influencing corporate rebranding indicator is the new image, and the weakest is repositioning. In addition, the study findings are contrary to this research, i.e research conducted by Caniago (2014) which is contrary to the results of this study. Caniago (2014) found that the relationship between corporate rebranding and brand equity was not significant.

There is a significant correlation between new identity with brand association of Radio Kencana Malang. It can be seen from the anova table and the coefficient table showing the significance value $<0.05$, thus hypothesis 2 is accepted. The results of this study refers to the theory of identity Melewar (2008) which states that, the identity is matters that include what the company wants to convey to differentiate and create a unique position in the environment where he operates. As for brand association, refers to the theory of Aaker (1991) which suggests brand association is anything related to the memory of a brand. Thus, it can be deduced that, the identity formed by companies to differentiate their characteristics from others comes also from associations formed by companies to create identity and form an image. So, this supports the results of research that mentions the existence of the relationship between identity with brand association.

There is a significant correlation between new identity with perceived quality Radio Kencana Malang. It can be seen from the anova table and the coefficient table showing the significance value $<0,05$, thus hypothesis 3 is accepted. Based on the theory described earlier and related to the significant relationship between new identity established by Radio Kencana with perceived quality, it can be concluded that the change in name (frequency number), new logo and slogan owned can be said to be successful and interesting for advertisers in helping to improve and strengthen the perception of the overall quality / excellence. In addition, from the results of this study, it can be said that with the name, logo 
and slogan as a new identity, it helps improve the advertisers quality perception of Radio Kencana. The results of this study are in line with research conducted by Pishdar et al. (2014) who found that identity positively affects directly on perceived quality in research using corporate image and corporate reputation variables to see the relationship between identity and perceived quality.

There is a significant correlation between new identity with brand loyalty Radio Kencana Malang. It can be seen from the anova table and the coefficient table showing the significance value $<0.05$, thus hypothesis 4 is accepted. Based on the theory described earlier and related to the significant relationship between new identity established by Radio Kencana with brand loyalty owned, it can be concluded that, the change in name (frequency number), new logo and slogan owned can be said to be successful and interesting for advertisers to help increase the loyalty of advertisers as loyal customers, making Radio Kencana the first choice in advertising on Radio and increasing the desire to recommend Radio Kencana on other advertisers. This is supported also by the research of Shirazi et al., (2013) which shows that there is an influence of identity on brand loyalty. Likewise with the results of research $\mathrm{Di}$ et al., (2009) which states that, identity can form a good image for consumers.

There is a significant correlation between new image and brand association of Radio Kencana Malang. It can be seen from the anova table and the coefficient table showing the significance value $<0.05$, thus hypothesis 5 is accepted. Significant correlations between the new image of the name, logo, and slogan of the brand association are in line with the results of Lee et al. (2011) which show that the updated image affects the respondent's association with a brand. The difference is, new image in their research resulted from $M$ \& A (Merger \& Acquisition).

There is a significant correlation between new image with perceived quality of Radio Kencana Malang. Thus hypothesis 6 is accepted. Significant correlations between the new image of the name, logo, slogan to perceived quality in line with the results of Lee et al., (2011) show that the new image has a significant correlation in perceived quality. Richardson et al., (1994) states that consumers tend to use images to evaluate a particular product or service. In addition, it supports research by Dodds et al., (1991) that image can serve as a quality warranty of a product or service. Thus, the better image owned will be the determinant of the better assessment of the quality product or service in front of consumers.

There is no significant correlation between new image and brand loyalty of Radio Kencana Malang. It can be seen from the anova table and the coefficient table showing the significance value $>0,05$ i.e 0,104 , thus hypothesis 7 is rejected. Based on the theory described earlier and related to the significant relationship between new image formed by Radio Kencana with brand loyalty owned, it can be concluded that it should be with the change in name (frequency number), new logo and slogan owned will be able to increase new image with positive, fun and good indicator on advertiser about Radio Kencana. However, this study shows contrary results, so the results of this study differ from the results of previous studies (Zins, 2001, Cretu \& Brodie, 2007; Lee et al. 2011) which shows that the image affects brand loyalty. In addition, study by Cretu \& Brodie's (2007 more specifically stated that the image not impact on consumer loyalty, but still suggests a positive image ownership because financial analysis shows that the image has an important position.

There is a significant correlation between repositioning and brand association Radio Kencana Malang. Hence hypothesis 8 is accepted. The repositioning efforts made by Radio Kencana by adjusting the name, slogan and logo have a significant correlation to brand association, in line with what was expressed by Muzellec \& Lambkin (2006), the right repositioning of the market can result in better brand association in the market and according to consumer desires. In addition, there are studies that contradict the results of this study, namely Zahid and Raja (2014) which identifies the repositioning of the company has no significant effect on brand loyalty. Renewal of names, slogans and logos to strengthen repositioning will be visible changes in the eyes of consumers, in this case advertisers or advertisers. Advertisers see the change from the interactions made with Radio Kencana both 
in the MoU (cooperation), in social media, as well as in off-air events held. From these interactions, advertisers associate the repositioning of Radio Kencana.

There is no significant correlation between repositioning and perceived quality of Radio Kencana Malang. It can be seen from the anova table and the coefficient table showing the significance value $>0,05$ that is equal to 0,317 , thus hypothesis 9 is rejected. This result is supported by Bamfo et al., (2018) which says that much rebranding activity by re-examining the company's business position and core values as a way to create brand refresh or brand differentiation in the market does not affect the changes in consumer perceptions of quality.

There is a significant correlation between repositioning and brand loyalty of Radio Kencana Malang. Thus hypothesis 10 is accepted. This research refers to Hassanien \& Baum's theory in Clements-Croome (2004) which states that repositioning is a process of marketing management change, either partly or as a totality. This study shows similar results with research conducted by Ampadu et al., (2015) found that there is a significant relationship between repositioning of brand loyalty. So also with Nyambane \& Ezekiel (2014) who found a positive impact of corporate rebranding on loyalty. However, it is contrary to that found by Zahid \& Raja (2014) which identifies the repositioning of companies has no significant effect on brand loyalty. Similarly, mentioned in Caniago et al., (2014) regarding his research conducted on TV stations, it was found that rebranding has no significant effect on brand loyalty.

\section{CONCLUSION}

This study shows a significant relationship between corporate rebranding to brand equity. Then, new identity with brand association, new image with brand association, repositioning with brand association, new identity with perceived quality, new image with perceived quality, repositioning with brand loyalty, and new identity with brand loyalty. However, there is no significant correlation between repositioning with perceived quality and new image with brand loyalty on Radio Kencana Malang. From the above exposure, it can be concluded that the media also need to pay attention to how they form their brand in the minds of their advertiser as shareholders. This is because it is related to financial or profit. If you decide to do rebranding activities, you must strategically mature, not to mention the media companies in order not to lower their perceptions, especially those affecting brand association, perceived quality and brand loyalty.

Limitations of this study are on the respondents who only focus on the advertiser, further research may be able to see from the audience and advertiser to enrich the data. To get richer results, can also do research with mix methode, that is quantitative and qualitative. In addition, this study only looks at how corporate rebranding relationship with brand equity, while in management strategy, there are many other variables that can affect the brand equity of a media company. Further research is expected to develop the concept that has been done in this research related to corporate rebranding and brand equity.

\section{REFERENCES}

1. Aaker, D. A. (1991). Managing brand equity capitalizing on the value of brand name. The Free Press, New York.

2. Aaker, D.A. (1996). Measuring Brand Equity Across Products And Markets. California Management Rev. 38(Spring), 102-120.

3. Abrams, R. M., \& LaPlante, A. (2008). Passion to Profits: Business Success for New Entrepreneurs. Planning Shop.

4. Ampadu, M. B., Aboagye, M. O., Ampadu, M., \& Ampadu, S. (2015). Corporate branding and consumer loyalty in the telecommunication industry: A case study of MTN Ghana. Net Journal of Business Management, 3 (3), 36-42.

5. Bamfo, B.A., Dogbe, C.S.K., \& Osei-Wusu, C. (2018). The Effects Of Corporate Rebranding On Customer Satisfaction And Loyalty: Empirical Evidence From The Ghanaian Banking Industry. Cogent Business \& Management, 5, 1-11. 
6. Caniago, A., Suharyono, Arifin, Z., \& Kumadji, S. (2014). The Effects of Service Quality and Corporate Rebranding on Brand Image, Customer Satisfaction, Brand Equity and Customer Loyalty (Study in Advertising Company at tvOne). European Journal of Business and Management, 6 (19), $118-126$

7. Chan-Olmsted, S.M., \& Kim, Y. (2001). Perceptions of Branding among Television Station Managers: An Exploratory Analysis. Journal of Broadcasting \& Electronic Media, 45 (1), 75-91.

8. Collange, V. (2008). L'impact de la substitution de marques sur l'e'valuation et l'intention d'achat du produit. Recherches et Applications en Marketing, 23 (2), 1-17.

9. Cretu, A. E., \& Brodie, R. J. (2007). The influence of brand image and company reputation where manufacturers market to small firms: A customer value perspective. Industrial Marketing Management, 36 (2), 230-240.

10. Delassus V.P., \& Descotes R.M. (2012). Brand name substitution and brand equity transfer. Journal of Product \& Brand Management. 21(2). 117-125.

11. Di, F., Chao, H., \& Panpan, Q. (2009). The Relationship between Brand Identity and Customer Loyalty (Master Thesis). Available from Proquest Databases, EBooks and Technology for Research.

12. Dodds, W. B., Monroe, K. B., \& Grewal, D. (1991). Effects of price, brand, and store information on buyers' product evaluations. Journal of marketing research, 307-319.

13. Durianto, D., Sugiarto, \& Budiman, L.J. (2004). Brand Equity Ten: Strategi Memimpin Pasar. Jakarta: Gramedia Pustaka Utama.

14. Einwiller, S., \& Will, M. (2002). Towards an integrated approach to corporate branding-an empirical study. Corporate Communications: An International Journal, 7 (2), 100-109.

15. Gaurav, K. (2008). Rebranding: Concepts, Cases and Application. Hyderabad: The Icfai University Press.

16. Kapferer, JN. (2004). The New Strategic Brand Management: Creating and Sustaining Brand Equity Long Term. Kogan Page, London.

17. Keller, K.L. (1993). Conceptualizing, Measuring, and Managing Customer-Based Brand Equity. Journal of Marketing, 57 (1), 1-22.

18. Kim, J., York, K.M., \& Lim, J.S. (2011). The Role of Brands In Recruitment: A MixedBrand Strategy Approach. Marketing Letters, 22 (2), 165-179.

19. Lee. H.M., Lee. C.C., \& Wu. C.C. (2011). Brand Image Strategy Affects Brand Equity After M\&A. European Journal of Marketing, 45, 1091-1111.

20. McDowell, W., \& Sutherland, J. (2000). Choice Versus Chance: Using Brand Equity Theory to Explore TV Audience Lead-in Effects, A Case Study. Journal of Media Economics, 13(4), 233- 247.

21. Mei Teh, G. (2009). Rebranding and Impact toward Brand Equity. World Journal of Social Sciences. 2 (4). 1- 14.

22. Melewar, T. C. (Ed.). (2008). Facets of corporate identity, communication and reputation. Routledge.

23. Merrilees ,B \& Miller, D.(2008). Principles Of Corporate Rebranding. European Journal of Marketing, Vol. 42 No. 5/6. 537-552.

24. Muzellec, L., Doogan, M., \& Lambkin, M. (2003). Corporate Rebranding- An Exploratory Review. Irish Marketing Review, 16 (2), 31- 40.

25. Muzellec, L \& Lambkin, M. (2006). Corporate rebranding: destroying, transferring or creating brand equity?. European Journal of Marketing, 40 (7/8), 803-824.

26. Nath Hanh Le, A., Ming Sung Ceng, J, Kuntjara, H., \& Ting-Jun Lin, C. (2014). Corporate rebranding and brand preference: brand name attitude and product expertise as moderators. Asia Pacific Journal of Marketing and Logistics. Vol. 26 No. 4, 2014, $602-$ 620.

27. Neuman, W. L. (2000). Social research method. University of Wisconsin at Whitewater.

28. Nyambane, M. M., \& Ezekiel, M. M. (2014). The relationship between rebranding and customer loyalty: The case of Kenya Power. International Journal of Science and Research, 4 (3), 995-1001. 
29. Oyedeji, T.A., (2007). The Relation Between the Customer-Based Brand Equity of Media Outlets and Their Media Channel Credibility: An Exploratory Study. The International Journal on Media Management, 9 (3), 116-125.

30. Petburikul, K. (2009). The Impact of Corporate Re-branding on Brand Equityand Firm Performance. Institute of International Studides, Ramkhamhaeng University Bangkok, Thailand. RU. Int. J, 3 (1).

31. Pishdar, M., Toloun, M.R.S.H., Farzianpour, F \& Rezaeiasl, M. (2014). Modeling The Effectiveness Of The Corporate Identity Mix In Perceived Quality And Customerrelated Brand Equity With Interpretive Structural Equations And Micmac Analysis. American Journal of Applied Sciences. 11 (4), 548-557

32. Porral, C.C., Fernandez V.A.M., \& Boga, O.J. (2014). Mass communication media credibility: an approach from the Credible Brand Model. Intercom RBCC São Paulo, Vol.37(2), 21-44.

33. Richardson, P. S., Dick, A. S., \& Jain, A. K. (1994). Extrinsic and intrinsic cue effects on perceptions of store brand quality. The Journal of Marketing, 28-36.

34. Shirazi, A., Lorestani H.Z., \& Mazidi A.K. (2013). Investigating the Effects of Brand Identity on Customer Loyalty from Social Identity Perspective. Iranian Journal of Management Studies (IJMS), 6 (2), 153-178

35. Simonin, B. L., \& Ruth, J. A. (1998). Is a company known by the company it keeps? Assessing the spillover effects of brand alliances on consumer brand attitudes. Journal of Marketing Research, 35 (1), 30-42.

36. Tong, X., \& Hawley, J.M. (2009). Measuring customer-based brand equity: Empirical evidence from the sportswear market in China. Journal of Product \& Brand Management, 18 (4), 262-271.

37. Zahid, S., \& Raja, N. S. (2014). Effect of rebranding and repositioning on brand equity considering brand loyalty as a mediating variable. Journal of Business and Management, 16 (1), 55-63.

38. Zeithaml, V.A. (1988). Consumer Perceptions Of Price, Quality And Value: A Means-end Model and Synthesis Of Evidence. Journal of Marketing, 52 (3), 2-22.

39. Zins, A. H. (2001). Relative attitudes and commitment in customer loyalty models: Some experiences in the commercial airline industry. International Journal of Service Industry Management, 12 (3), 269-294. 